Review article

\title{
A review of human biomonitoring in selected Southeast Asian countries
}

\author{
Zohar Barnett-Itzhaki ${ }^{\mathrm{a}, \mathrm{b}, *}$, Marta Esteban López ${ }^{\mathrm{c}}$, Naveen Puttaswamy ${ }^{\mathrm{d}}$, Tamar Berman ${ }^{\mathrm{a}}$ \\ a Ministry of Health, Jeremiya Street 39, Jerusalem 9446724, Israel \\ b Bioinformatics Department, School of Life and Health Science, Jerusalem College of Technology, Jerusalem, Israel \\ c Área de Toxicología Ambiental, Centro Nacional de Sanidad Ambiental, Instituto de Salud Carlos III, Madrid, Spain \\ ${ }^{\mathrm{d}}$ Center for Air Quality, Climate and Health, Department of Environmental Health Engineering, Sri Ramachandra Medical College and Research Institute, Chennai, India
}

\begin{abstract}
A B S T R A C T
Rapid development and industrialization in Southeast (SE) Asia has led to environmental pollution, potentially exposing the general population to environmental contaminants.

Human biomonitoring (HBM), measurement of chemical and/or their metabolites in human tissues and fluids, is an important tool for assessing cumulative exposure to complex mixtures of chemicals and for monitoring chemical exposures in the general population.

While there are national HBM programs in several developed countries, there are no such national programs in most of the SE Asian countries. However, in recent years there has been progress in the field of HBM in many of the SE Asian countries.

In this review, we present recent HBM studies in five selected SE Asian countries: Bangladesh, Indonesia, Malaysia, Myanmar and Thailand. While there is extensive HBM research in several SE Asian countries, such as Thailand, in other countries HBM studies are limited and focus on traditional environmental pollutants (such as lead, arsenic and mercury). Further development of this field in SE Asia would be benefited by establishment of laboratory capacity, improving quality control and assurance, collaboration with international experts and consortiums, and sharing of protocols and training both for pre-analytical and analytical phases.

This review highlights the impressive progress in HBM research in selected SE Asian countries and provides recommendations for development of this field.
\end{abstract}

\section{Background}

Southeast (SE) Asia is highly populated and is considered as one of the fastest developing regions in the world, with increasing demand for electricity and fuels. In addition, many SE Asian countries underwent rapid industrialization, driven by foreign direct investments (Diaconu, 2014) and due to relatively cheap labor force. In some cases, there is widespread pollution of air, water and soil and minimal actions to mitigate the pollution (Damrongsiri et al., 2016). Such processes may lead to high population exposure to industrial and transportation pollution and may result in adverse health outcomes.

As a result of growing pollution, the population in SE Asia may be exposed to chemicals via occupational exposures and through their diet, air, water, and consumer products, via dermal, oral uptake or inhalation. Exposure to chemical mixtures via multiple pathways complicates exposure characterization using traditional environmental media concentration estimations. Human biomonitoring (HBM), which is a direct measurement of chemicals or their metabolites in human tissues and fluids (National Research Council (NRC), 2006), is an effective tool for measuring human exposure to environmental chemicals.

Population based HBM can identify specific at risk groups for high environmental exposures and can therefore by used to design public health interventions. For example, population-based biomonitoring in New York City (NYC) identified skin care products as a previously unrecognized source of exposure to inorganic mercury among NYC residents (McKelvey et al., 2011). In response, the NYC Health Department embargoed products and notified store owners and the public that skin-lightening creams and other skin care products that contain mercury are dangerous and illegal.

HBM is also an important tool for understanding health effects of environmental chemicals and population susceptibility to these compounds. HBM can be used in epidemiological studies in combination with health data to demonstrate an association between the body burden of pollutants and their health effects (World Health Organization (WHO) Europe, 2015). Finally, HBM is a powerful tool for tracking the effectiveness of public health interventions, such as phasing out of lead in gasoline and restrictions on smoking in public places (Centers for Disease Control and Prevention (CDC), 2017).

\footnotetext{
* Corresponding author at: Ministry of Health, Jeremiya Street 39, Jerusalem 9446724, Israel.

E-mail address: zohar.barnett@moh.gov.il (Z. Barnett-Itzhaki).
} 
In this framework and considering the usefulness of HBM to perform an integrated assessment of environmental exposure, there is increasing awareness for HBM in developed countries. Several countries have already initiated HBM national programs in order to improve the detection, diagnosis, treatment and prevention of disease, injury, and harmful environmental exposures in populations (Centers for Disease Control and Prevention (CDC), 2017).

Despite evidence of increased exposure, there are no national HBM programs in most of the SE Asian countries. In recent years, however, HBM studies have been conducted in several countries in South-East Asia. In November 2016, the World Health Organization organized a Workshop on Human Biomonitoring (HBM) to Support Chemical Risk Assessment in Bangkok, Thailand. Participants from several SE Asian countries (Indonesia, India, Bhutan, Thailand, Malaysia and Myanmar) presented HBM experiences, goals achieved and challenges for the future.

This review presents recent HBM studies in five selected SE Asian countries. The purpose of the review is to highlight data and progress in the field of HBM in SE Asia and to provide recommendations for further development of this field.

\section{Methods}

We searched PubMed for reviews and papers published in English after 1998 and focused on those published after 2003. The searched terms were: ("human biomonitoring" or "biomonitoring") and ("lead" or "arsenic" or "cadmium" or "chromium" or "mercury" or "organophosphates" or "organochlorines" or "organochlorides" or "dioxins" or ("organic" and "toxins") or "PFOS" or "PFOA" or "cotinine" or "air pollution" or "polluted air" or "particulate matter" or "air quality" or "water"), for the relevant countries, excluding papers regarding indoor air pollution. In addition, we searched for relevant documents published by the World Health Organization (WHO) as well as the U.S Centers for Disease Control and Prevention (CDC). We excluded studies in occupational settings. We briefly present results of these studies. For a subsample of studies, we evaluated quality control and quality assurance $(\mathrm{QC} / \mathrm{QA})$, such as the sampling strategy, the conditions under which the samples were shipped and stored, the laboratory accreditations and any international collaboration (Supplementary Table 1).

\section{Results}

We found a total of 47 HBM studies conducted in 2003-2017 (Table 1 ). The vast majority were conducted in Thailand; the majority focused on exposure to heavy metals.

\section{Thailand}

Thailand is an agricultural country that went through rapid and massive industrialization that led to a variety of environmental problems, particularly air pollution. The major sources of air pollution in
Thailand are industry, transportation, and biomass burning (VichitVadakan and Vajanapoom, 2011). Due to high ambient levels of lead, the Thai Government initiated a program to eliminate lead in gasoline (towards the end of the previous century), which was considered as successful (Sayeg, 1998). In addition, intensive farming in the last decades contributed to exposure of the Thai population to a variety of toxic pesticides and also to water pollution.

In recent years there have been several biomonitoring studies in Thailand. Most of the HBM studies in Thailand are focused on heavy metals, mostly lead, and on pesticides.

\subsection{Organic compounds}

Thailand is an agricultural country and one of the world's major food exporters. There is widespread use of pesticides to protect crops and to increase yields. There was a four-fold increase in the usage of pesticides in the last decade (Panuwet et al., 2012).

Organochlorines were widely used in the last century but most were phased out gradually in crop production in Thailand in the late 1970s. However, due to the stability and persistence of organochlorines and their residues, they are still found in nanogram levels in water, sediment, and aquatic organisms collected in Thailand's agricultural regions (Panuwet et al., 2012). Currently, there is widespread use of organophosphates in Thai agriculture. This widespread use leads to high rate of intoxication due to exposure to organophosphates. Therefore, biomonitoring of organochlorines and of organophosphates is of high importance and was conducted in several studies published in recent years.

\subsubsection{Organochlorines}

Stuetz et al. (2001) measured the levels of DDT, heptachlor, HCB and HCH in 25 breast milk samples taken from Thai women that came from regions where DDT was widely used (Stuetz et al., 2001). DDT was detected in all samples (median level of $209 \mathrm{ng} / \mathrm{mL}$ ), while heptachlor was detected in 15 of the samples (median level of $4.4 \mathrm{ng} / \mathrm{mL}$ ). The estimated daily intakes of DDT, heptachlor and heptachlor-epoxide by breastfed infants exceeded the acceptable daily intakes as recommended by the WHO, by up to 20 times.

In a study published in 2006, Asawasinsopon et al. collected maternal blood and umbilical cord blood from 39 Thai mothers and their newborns. Levels of $\mathrm{pp}^{\prime}$-DDE (1,1-dichloro-2,2-di(4-chlorophenyl) ethylene), p-p'-DDT (1,1,1-trichloro-2,2-di(4-chlorophenyl)ethane), pp'-DDD (1,1-dichloro-2,2-di(4-chlorophenyl) ethane, dieldrin, and total thyroxine (TT(4)) were measured both in the maternal blood and in newborn cord blood. The researchers found high levels of $\mathrm{pp}^{\prime}$-DDE and p-p'-DDT in both matrices (maternal bloods and newborn cord bloods). The researchers also found a positive association between maternal blood and newborn cord blood levels of p-p'-DDT, p-p'-DDE, p-p'-DDD, and dieldrin. In addition, a negative association was found between the newborn's TT(4) and the newborn's levels of organochlorines (p-p'-DDT, $\mathrm{p}-\mathrm{p}^{\prime}$-DDE, and $\mathrm{p}-\mathrm{p}^{\prime}$-DDD), suggesting that exposure to DDT and its

Table 1

Summary of the biomonitoring studies reviewed from select SE Asian countries (2003-2017).

\begin{tabular}{|c|c|c|c|}
\hline Country & Category & Heavy metals & Organic \\
\hline \multirow{2}{*}{ Thailand } & Number of studies & 11 & 9 \\
\hline & Compounds & Lead, cadmium, arsenic, mercury & Organophosphates, organochlorines \\
\hline \multirow[t]{2}{*}{ Bangladesh } & Number of studies & 8 & 1 \\
\hline & Compounds & Lead, cadmium, arsenic, selenium & Organochlorines \\
\hline \multirow[t]{2}{*}{ Myanmar } & Number of studies & 2 & - \\
\hline & Compounds & Lead & - \\
\hline \multirow[t]{2}{*}{ Malaysia } & Number of studies & 2 & 8 \\
\hline & Compounds & Lead, cadmium, arsenic, mercury & Dioxins, organochlorines, perfluorinated compounds (PFOS/PFOA), phthalates, bisphenols, nicotine \\
\hline \multirow[t]{2}{*}{ Indonesia } & Number of studies & 5 & 1 \\
\hline & Compounds & Lead, mercury & Polybrominated diphenyl ethers (PBDE), organochlorines \\
\hline Total & & 28 & 19 \\
\hline
\end{tabular}


metabolites during fetal development effects thyroid hormonal status (Asawasinsopon et al., 2006).

In an additional study conducted by the previous group, blood samples from 97 Thai men were collected and plasma levels of DDT, its metabolites and reproductive hormones (17beta-estradiol (E2), testosterone, luteinizing hormone (LH), and follicle stimulating hormone (FSH)) were measured (Vaneesorn et al., 2006). Very high levels of p, $\mathrm{p}^{\prime}$ DDE (median of $4057.7 \mathrm{ng} / \mathrm{g}$ lipids), and of p,p'-DDT were detected in all plasma samples. Of note, plasma p,p'-DDT levels were positively associated with years of residence and years of DDT usage for farming. The researchers found a negative association between plasma E2 levels and plasma p, $\mathrm{p}^{\prime}$-DDE levels. Additionally, there was a positive association between plasma E2 levels and plasma 1,1-dichloro-2-(2-chlorophenyl)-2-(4-chlorophynyl)ethylene (o,p'-DDE) levels.

\subsubsection{Organophosphates}

In 2014 Kongtip et al. collected urine samples from Thai women and tested them for organophosphate metabolites (dimethyl phosphate (DMP), diethyl phosphate (DEP), diethyl thiophosphate (DETP), and diethyl dithiophosphate (DEDTP)) at 28 weeks of pregnancy, at delivery, and two months postpartum (Kongtip et al., 2014). The researchers also tested the mothers' exposure to pesticides at home and at work using questionnaries. Urinary organophosphate metabolites, at 28 weeks of pregnancy, at delivery, and two months postpartum, fluctuated depending on maternal pesticide exposures both at home and in agricultural fields.

In 2015 Liu et al. quantified organophosphates (OPs) levels in Thai farmers and farmers' families, testing 72 urine samples. Samples were collected in the spraying season and were analyzed for DEP, DETP, DEDTP, DMP, dimethyl thiophosphate (DMTP), and dimethyl dithiophosphate (DMDTP). The researchers detected urinary dialkyl phosphate (DAP) in all participants (farmer, spouse and children). The geometric mean (GM) levels found in the farmers $(4.68 \mu \mathrm{g} / \mathrm{g})$ was higher than the GM level of the spouses $(4.04 \mu \mathrm{g} / \mathrm{g})$, which was much higher than the GM level of the children $(3.12 \mu \mathrm{g} / \mathrm{g}$ ). (Liu et al., 2015). The researchers modelled the relationships between the farmer, the spouse and the children and found that the farmer's DAPs levels affect the spouse's DAPs levels $(p=0.001)$ and the spouse's DAPs levels affect the children's $(p=0.01)$.

In 2014, Rohitrattana et al. published two studies of pesticides biomonitoring in children living in different areas in Thailand. The first study quantified urinary organophosphates (OP) and found that most OP metabolites were significantly higher in participants who lived in a rice farming community than those who lived in aqua-cultural farming areas (Rohitrattana et al., 2014). The researchers also found an association between the frequency of OPs application on rice farms and the urinary DAP metabolite levels. The researchers showed that increasing TCPy (3,5,6-trichloro-2-pyridinol, a metabolite of chlorpyrifos and chlorpyrifos-methyl) levels were significantly associated with: proximity to rice farm, presence and playing in the farm, and the presence of observable dirt accumulated on the child's body (Rohitrattana et al., 2014). The second study that focused on Pyrethroid insecticides (PYR) and its' metabolites showed slightly increased urinary PYR metabolites during the wet season compared with the dry season (Rohitrattana et al., 2014). Increased urinary PYR metabolites was associated with the frequency of PYR use in farms and households, proximity to rice farms, and playing in rice farm.

In a study from 2015, researchers showed that children of rice farmers had significantly higher concentrations of DAP, TCPy and DCCA (a PYR metabolite) than aquaculture farm children (Fiedler et al., 2015). There was no association with children's neurobehavioral parameters.

Naksen et al. (2015) used a birth cohort (the Study of Asian Women and Offspring's Development and Environmental Exposures SAWASDEE cohort) in order to evaluate chemical exposures and their relation to birth outcomes and infant neurodevelopment in 52 pregnant farmworkers (Naksen et al., 2015). In mothers with low paraoxonase 1 (PON1) activity, the newborn head circumference and the birth weight were negatively correlated with the maternal total DEP and total DAP.

\subsection{Heavy metals}

Biomonitoring of lead in Thailand has been conducted since the late 90 's of the previous century (Wananukul et al., 1998). HBM studies in Thailand to detect heavy metals, including lead, are conducted both among the general population, and also among workers in a variety of industries.

Many of the general population biomonitoring studies are conducted on populations living in areas contaminated by heavy metals. Unfortunately, there are many such areas, mostly in northern Thailand.

\subsubsection{Lead and cadmium}

Sirivarasai et al. (2004) examined the effects of exposure to lead and cadmium on blood pressure among 212 Thai men (ages 34-53). Blood lead geometric mean concentration was $363.11 \mathrm{nmol} / \mathrm{L}(13.2 \mu \mathrm{g} / \mathrm{dL})$ and blood cadmium geometric mean was $8.09 \mathrm{nmol} / \mathrm{L}(0.3 \mu \mathrm{g} / \mathrm{dL})$. An increase in systolic blood pressure was significantly correlated with increasing blood lead, while blood cadmium showed no significant correlation with blood pressure (Sirivarasai et al., 2004).

In 2005 researchers examined lead in whole blood and saliva taken from 29 men and women living in an area contaminated from lead mining in Thailand (Thaweboon et al., 2005). The blood lead $(663 \mathrm{nmol} / \mathrm{L}, 24.03 \mu \mathrm{g} / \mathrm{dL})$ was higher than that in the saliva $(5.69 \mu \mathrm{g} /$ $\mathrm{dL})$. There were higher levels of lead in the males' blood than in the females'.

Swaddiwudhipong et al. (2013) quantified blood lead levels among Thai children, in order to test if exposure to lead-acid batteries is associated with high levels of lead in the blood (Swaddiwudhipong et al., 2013). 254 children (aged 1-14) participated in the study and the mean blood lead level was $9.8 \mu \mathrm{g} / \mathrm{dL}$. Older children had lower blood lead levels. More than half of the children living in a house with vented leadacid batteries had high blood lead levels, while less than a quarter of children living in a house without vented lead-acid batteries had high blood lead levels. The researchers collected ambient samples in houses with vented lead-acid batteries, and found lead contamination in the dust, in drinking-water kept in containers, but not in tap water.

In 2004, Australian researchers investigated 197 Thai men and women to quantify urinary cadmium levels (Satarug et al., 2004). The researchers found cadmium levels with a geometric mean of $0.46 \mu \mathrm{g} / \mathrm{g}$ (in the range of 0.04 to $3.84 \mu \mathrm{g} / \mathrm{g}$ ). Females' (but not males') cadmium levels were negatively correlated with serum ferritin, suggesting that exposure to cadmium decreases iron levels. In addition, cadmium levels were positively correlated with cigarette smoking. Similar results were reported in a paper from 2010 (Apinan et al., 2010).

In another study from 2011 the researchers examined 314 Thai subjects living in cadmium contaminated areas (Boonprasert et al., 2011). Most of the subjects had low urinary and blood cadmium levels (cadmium levels below $1 \mu \mathrm{g} / \mathrm{g}$, and below $5 \mu \mathrm{g} / \mathrm{L}$ in blood). The researchers succeeded to predict cadmium levels using on a regression model based on gender, residential areas, bamboo/chicken/beans/ pork/fish/liver consumption, and smoking.

A study from 2014 quantified cadmium levels in blood and urine samples from 600 subjects (older than 40 years) living in cadmium contaminated areas in north Thailand, 81 subjects living in non-contaminated areas in Thailand (Nishijo et al., 2014). The researchers investigated the health effects of exposure to cadmium by measuring the levels of two marker renal proteins ( $\beta 2-\mathrm{MG}$ and NAG). The GMs of cadmium (both in blood and in urine) were statistically significant higher in samples taken from residents in contaminated areas than in samples taken from non-contaminated ones (for example: $6.9 \mu \mathrm{g} / \mathrm{L} /$ $6.3 \mu \mathrm{g} / \mathrm{g}$ creatinine blood/urinary cadmium in men from contaminated areas in comparison to $0.9 \mu \mathrm{g} / \mathrm{L} / 0.5 \mu \mathrm{g} / \mathrm{g}$ creatinine in men from non- 
contaminated areas, and similar trends in women). Linear regression analyses showed a dose-effect relationship between cadmium exposure and renal markers, indicating that living in contaminated areas may influence renal function.

A paper published in 2015 by the same group, compared cadmium levels in 751 subjects (age > 35) from contaminated areas, with those in 682 people from non-contaminated areas (Swaddiwudhipong et al., 2015). Cadmium levels in subjects living in the contaminated areas (GM of $2.96 \mu \mathrm{g} / \mathrm{g}$ creatinine) was higher than the levels in the control group compared to subjects from non-contaminated areas (GM of $0.60 \mu \mathrm{g} / \mathrm{g}$ creatinine). Additionally, contaminated areas' subjects had a higher prevalence of renal dysfunction, bone mineral loss, hypertension and urinary stones than those from non-contaminated areas.

In a study published by the same group in 2015,594 primary school children were tested for urinary cadmium, $\beta 2-\mathrm{MG}$, and calcium (Swaddiwudhipong et al., 2015). 19\% of the children had urinary Cd $\geq 1 \mu \mathrm{g} / \mathrm{g}$, which was significantly higher in girls and in children that consume rice grown in contaminated areas. Higher urinary cadmium was associated with higher levels of urinary $\beta 2-\mathrm{MG}$ and calcium, but not with higher blood pressure.

\subsubsection{Arsenic and mercury}

A series of studies measured arsenic levels in 32 Thai pregnant women that were exposed to arsenic in groundwater (Fry et al., 2007). Toenail samples were collected from mothers during pregnancy, and cord blood samples were collected from the newborns. High levels of arsenic ( $\geq 0.5 \mu \mathrm{g} / \mathrm{g}$ ) were found in 21 out of the 32 pregnant women. In addition, arsenic exposed newborns had significantly higher levels of arsenic in cord blood. A gene expression analysis was conducted on the cord blood samples of the newborns and showed an alteration in the gene expression of newborns of exposed women (Fry et al., 2007). In a follow-up study conducted in 2013, nails, saliva and urine samples were collected from the same children, who continued to live in the same arsenic-contaminated areas (Hinhumpatch et al., 2013). The researchers found high levels of arsenic in the three tissues. A gene expression analysis showed a significant increase in oxidative DNA damage in exposed children.

In a study from 2011 of 873 schoolchildren aged 6-13 years living in four sites near the eastern seaboard industrial estates of the Gulf of Thailand, in most children blood mercury did not exceed threshold values (Teeyapant et al., 2015). However, in 36 children blood mercury exceeded the HBM-1 value of $5 \mu \mathrm{g} / \mathrm{L}$.

\section{Bangladesh}

Bangladesh is mostly an agricultural country. The major industry in Bangladesh is textile. In addition to environmental risks stemming from agriculture and the textile industry, an environmental threat in Bangladesh is arsenic found in drinking water: up to $50 \%$ of the population in Bangladesh is considered to be at risk from drinking Ascontaminated water. The Government of Bangladesh adopted a National Arsenic Policy and Mitigation Action Plan in 2004 for providing arsenic safe water to all the exposed population. Consequently, drinking water monitoring shows a trend of mitigating As-drinking water (Edmunds et al., 2015). Additionally, waterways in Bangladesh are also polluted with metals and heavy metals, due to discharge of agricultural, domestic and industrial wastes directly into the waterways (Kibria et al., 2016).

Bangladesh's capital - Dhaka and its surroundings suffer from severe air pollution, especially during the dry season (November-April). Air monitoring conducted in 2012-2015 revealed extremely high levels of ambient $\mathrm{PM}_{10}$ and $\mathrm{PM}_{2.5}$ which are six to 13 times greater than the World Health Organization (WHO) guideline value (Rana et al., 2016). Furthermore, use of biomass fuel for cooking is still common in Bangladesh, exposing the population to more pollutants (Haque et al., 2016).

\subsection{Organic compounds}

\subsubsection{Organochlorines}

In 2009 Zamir et al. studied persistent organic halogenated pollutants in blood samples taken from Bangladeshi men and women with different occupations (i.e.: students, garment industry workers, employees at the Power Development Board (PDB), fishermen and fishermen wife's) (Zamir et al., 2009). The researchers quantified hexachlorobenzene (HCB), hexachlorocyclohexane isomers $(\alpha-\mathrm{HCH}, \beta-\mathrm{HCH}$, $\gamma-\mathrm{HCH}$ and $\delta$ - $\mathrm{HCH}$ ), the DDT group of chemicals, chlordane compounds (trans-chlordane, cis-chlordane, oxychlordane, trans-nonachlor, transheptachlorepoxide) methoxychlor and mirex. High levels of p,p'-DDE in all groups, with $\mathrm{p}, \mathrm{p}^{\prime}$-DDT/Sigma DDT ratios were found, indicating recent and ongoing DDT exposure. Male garment industry workers had statistically significantly higher levels of p,p'-DDT in comparison to fishermen (all males): median of $2300 \mathrm{ng} / \mathrm{g}$ lipids in the garment workers' samples, and $640 \mathrm{ng} / \mathrm{g}$ lipids in the fishermen's samples. $\beta$ $\mathrm{HCH}$ was highly abundant, especially among students, indicating the use of technical $\mathrm{HCH}$ products instead of Lindane $(\gamma-\mathrm{HCH})$. Very low concentrations of polychlorinated biphenyls (PCB) were present in all groups.

\subsection{Heavy metals}

\subsubsection{Lead}

Gleason et al. (2014) quantified lead levels in the blood of 309 Bangladeshi children aged 20-40 months. The researchers found that $78 \%$ of the children had blood lead concentrations above $5 \mu \mathrm{g} / \mathrm{dL}$ (the reference level currently set by the US Centers for Disease Control and Prevention (CDC)), and $27 \%$ had concentrations above $10 \mu \mathrm{g} / \mathrm{dL}$. The researchers randomly selected 28 children (among the high and low blood lead levels), administered a questionnaire, obtained soil, dust, rice, and spice samples, in addition to water and environmental samples from the selected children's neighborhoods. The researchers found high lead concentrations in many turmeric samples (up to $483 \mathrm{ppm}$ ). However, they did not find a strong correlation between turmeric lead concentrations in the child's house and blood lead concentration (Gleason et al., 2014).

\subsubsection{Arsenic and selenium}

As opposed to other chemicals and pollutants, arsenic can occur naturally in groundwater without an anthropogenic source of contamination. In Bangladesh over 50 million people are exposed to naturally occurring arsenic concentrations exceeding the World Health Organization's (WHO) guideline of $10 \mu \mathrm{g} / \mathrm{L}$.

Rahman et al. (2009) aimed to evaluate the association between prenatal arsenic exposure, with birth measures (weight, length, head and chest circumferences). The researchers used data from 1578 mother-infant pairs that includes measurements of urinary arsenic collected at around gestational weeks 8 and 30 . When analyzing cases with low levels of arsenic ( $<100$ microgram/L in urine), the researchers found that birth weight decreased by $1.68 \mathrm{~g}$ for each $1 \mu \mathrm{g} / \mathrm{L}$ increase of arsenic in urine. However, no negative effect was found at higher levels of arsenic exposure (Rahman et al., 2009).

George et al. (2013), studied the relationship between blood selenium and urinary and blood arsenic using a cohort of 1601 adults and 287 children living in a moderately arsenic-contaminated rural area in Bangladesh (George et al., 2013). The urinary arsenic levels in adults were higher than those in children (adults: $90.7 \pm 104 \mu \mathrm{g} / \mathrm{L}$ in the range of $1-1138 \mu \mathrm{g} / \mathrm{L}$, children: $78.2 \pm 72.5 \mu \mathrm{g} / \mathrm{L}$ in the range of $6-461 \mu \mathrm{g} / \mathrm{L})$. The researchers showed a statistically significant inverse relationship between blood selenium and urinary arsenic concentrations in both adult and children, and a statistically significant inverse relationship between blood selenium and blood arsenic in children.

Isalem et al. (2014) chose 30 mother-infant pairs and quantified arsenic in breastmilk, in addition to urinary arsenic both from the 
mothers and their infants in several time points (1, 6 and 9 months postnatal). The median arsenic concentration in breastmilk was $0.5 \mu \mathrm{g} / \mathrm{L}$. Of note, with the progression of time, arsenic concentration in infant's urine increased up to $0.13 \mu \mathrm{g} / \mathrm{L}$. The researchers found no correlation between the arsenic milk levels and the infants' urinary arsenic. Dimethyl arsenic acid (DMA) was the predominant arsenic metabolite in infant urine (Islam et al., 2014).

A review published in 2015 describes the Bangladeshi government efforts to cope with groundwater arsenic contamination (Chakraborti et al., 2015). The School of Environmental Studies (SOES, Jadavpur University, Kolkata, India), in collaboration with Dhaka Community Hospital collected and analyzed thousands of biological samples (hair, nail, urine and skin scales) and foodstuffs for arsenic.

Nahar et al. (2014) investigated the intelligence quotient (IQ) of 408 children living in Bangladeshi areas exposed to high levels of arsenic groundwater (Nahar et al., 2014). The researchers collected urine and water samples from two groups of children: ages 4-5 and ages 9-10. They quantified urinary arsenic and estimated the children's IQ and found an association between urinary arsenic and reduced intellectual function in a dose-response manner. The association between urinary arsenic and decreased IQ was stronger than the association between water level of arsenic and decreased IQ.

\subsubsection{Cadmium}

Kippler et al. (2010) assessed cadmium exposure in young children, born to women that were exposed to cadmium via rice. The researchers measured urinary cadmium in samples taken from 350 children (ages 18 months to 5 years), and from 92 children at the age of 3 months, in addition to cadmium in the mothers' breastmilk, saliva and urine. Median urinary cadmium ranged from 0.16 to $0.30 \mu \mathrm{g} / \mathrm{L}$, and were $0.6 \mu \mathrm{g} / \mathrm{L}$ in mothers. There was a correlation between the cadmium concentration in urine samples from infants and the maternal breastmilk, saliva, and urine. The researchers suggested that rice is most likely the main source of exposure, with the median of $47 \mu \mathrm{g} / \mathrm{kg}$ (Kippler et al., 2010).

In another study by this group, Kippler et al. (2012) evaluated the associations between cadmium exposure and neurobehavioral development in preschool children (Kippler et al., 2012). They studied a 1305 mother-child cohort in rural Bangladesh, and quantified urine cadmium levels in the early pregnancy. When the child was 5 years old they quantified the u-Cd and performed a set of tests, including IQ, Verbal IQ (VIQ), Performance (PIQ), and Full-scale IQ (FIQ). Using linear regression, the researchers found that doubling of maternal urinary cadmium was inversely associated with VIQ ( -0.84 points), PIQ $(-0.64)$, and FSIQ $(-0.80$ points). There was a weaker association between the child urinary cadmium with VIQ, FSIQ, but not with PIQ. The researchers concluded that early-life low-level cadmium exposure was associated with lower child intelligence scores in the study cohort.

\section{Myanmar}

Myanmar is mostly an agricultural rather than an industrialized country, but suffers from both high ambient air pollution and indoor air pollution due to transportation, tobacco smoking, and also biomass cooking (World Health Organization (WHO), 2016). According to the Global Burden of diseases (GBD), there were 13.31 per 100,000 deaths in Myanmar in 2015 due to air pollution (Cohen et al., 2017). In addition, there is evidence of groundwater contamination by inorganic pollutants, such as arsenic, manganese, fluoride, iron, and uranium (Bacquart et al., 2015). However, there is almost no biomonitoring research in this country.

\subsection{Heavy metals}

6.1.1. Lead

In 2011, American researchers from Georgia and Indiana investigated lead in the blood of 197 Burmese children under the age of six years living in Indiana, USA (Ritchey et al., 2011). The researchers found that 14 of the 197 children that were tested, had elevated venous blood lead levels (above $10 \mu \mathrm{g} / \mathrm{dL}$ ), four of these children were born in the USA. Possible reasons for the elevated lead levels found in the children's blood are the use of traditional ethnic remedies and cosmetics that contain high levels of lead.

An additional study that measured lead levels in Burmese children's blood from 2012, checked the blood of children aged 6 months to 14 years from refugee camps in the Thailand-Myanmar border (Mitchell et al., 2012). The researchers tested lead levels in 642 children's blood and found that most of the children $(577,89.9 \%)$ had detectable capillary blood lead levels, 64 of them had capillary blood lead levels above $10 \mu \mathrm{g} / \mathrm{dL}$, and 33 of them had venous blood levels above $10 \mu \mathrm{g} /$ dL. Risk factors for elevated blood lead in children younger than two years old included: hemoglobin levels below $10 \mathrm{~g} / \mathrm{dL}$, exposure to car batteries, and putting metal objects in their mouths.

\section{Malaysia}

As a developing country, with rapid industrial and economic growth, the quantities of waste, including heavy metals, arsenic and mercury, produced in Malaysia are annually increasing. Of note, the Malaysian government has not included heavy metal content in river water as a parameter in the Malaysian water quality index, and a variety of toxic metals, such as arsenic, chromium, mercury, lead, and cadmium, contaminate river water, reach drinking water, and consequently potentially risk human health. Poon et al. have shown that many of Malaysian rivers are highly polluted with heavy metals, at concentrations higher than national and international standards (Poon et al., 2016).

Rapid industrial and economic growth, in addition to population growth and aggressive consumerism in the past five decades enhanced the manufacturing and the Malaysian use of consumer products containing polychlorinated biphenyls (PCBs) and polybrominated diphenyl ethers (PBDEs) (Kaw and Kannan, 2017). This exposes various Malaysian populations to PCBs and PBDEs.

\subsection{Organic compounds}

Sudaryanto et al. measured levels of PCDD, PCDFs, PCBs, organochlorine pesticides and TCP in samples collected from primipara mothers (Sudaryanto et al., 2005).

Tanabe and Kunisue reviewed the contamination of persistent organic pollutants (PCDDs, PCDFs, PCBs, DDT and metabolites, $\mathrm{HCH}$ isomers, Chlordane compounds and HCB) in breast milk during 1999-2003 in seven Asian countries (Japan, China, Phillipines, Vietnam, Cambodia, India, Malaysia and Indonesia) (Tanabe and Kunisue, 2007). The studies were conducted in samples collected from general population and from residents around the open dumping sites of municipal wastes. They found organic compounds in all samples with DDTs, HCHs and PCBs showing the highest levels. Considering the levels of toxic equivalents (TEQs) their results were slightly higher than those in other developing countries but much lower than those of industrialized ones.

Perfluorooctane Sulfonate (PFOS) and Perfluorooctanoic acid (PFOA) was also studied in human breast milk samples $(n=184)$ recently in seven Asian countries including Malaysia (Tao et al., 2008). Their results were similar or lower than results from USA and Europe (Sweden and Germany).

In 2011, Zhang et al. studied the urinary Bisphenol A (BPA) levels in seven Asian countries, Malaysia included, to establish a baseline value, to identify geographic patterns and profiles, and to estimate daily intakes (Zhang et al., 2011). From May to July 2010, 29 urine samples were collected in Malaysia (Kuala Lumpur) from donors with mean age of $30 \pm 9$ years (10 men and 19 women). The geometric mean (IC95\%) were $1.93 \mu \mathrm{g} / \mathrm{g}(1.21-4.09)$ and a range of $<$ LOQ-30.0 $\mu \mathrm{g} / \mathrm{g}$. BPA 
levels observed in Malaysia were very low compared to the other countries, were only higher than those in Japan $(0.58 \mu \mathrm{g} / \mathrm{g})$ and were less than half of Kuwait, the country with the highest levels $(2.45 \mu \mathrm{g} / \mathrm{g})$. Results were below those found in NHANES 2003-2004 $(2.6 \mu \mathrm{g} / \mathrm{g})$ but of note, the sample size was very limited.

Guo et al. investigated the levels of 14 phthalates metabolites in 262 samples collected in the general population aged 21 to 49 years in the same seven countries (29 samples from Malaysia) and found measurable levels in all the samples (Guo et al., 2011). The levels observed in Malaysia for the sum of the 14 metabolites was the lowest $(94.4 \mathrm{ng} / \mathrm{mL})$ vs the highest found in Kuwait (1050 ng/mL). The highest occurrence was found for MMP, MEP, MiBP, MBP and DEHP metabolites accounting for $>95 \%$ of the total. The phthalates profiles were country dependent. Levels of MMP, MCHP, MDP and MNP were not detected in samples from Malaysia. For the other metabolites, levels followed the increasing order of MCCP $<$ MBzP $<$ MEHP $<$ MEOHP < MEHHP < MECPP < MCMHP < MiBP < MBP < MEP.

In 2012, BPA levels were analyzed in surface water, drinking water and plasma (Santhi et al., 2012). Of note, $98 \%$ of the drinking water in Malaysia comes from rivers. The researchers studied the BPA levels in samples from outlets of municipal sewage treatments plants, industry and wet markets in order to assess the pollution load from these sources. To complete the study, they collected tap water, bottled water and plasma samples from 101 volunteers living in the Langat river basin, so these results cannot be generalized to the general Malaysian population. $17 \%$ of the plasma samples had detectable levels of BPA in a range of $0.81-3.65 \mathrm{ng} / \mathrm{mL}$. The group of $<30$ years age had the highest detection rate, followed by the age groups 30-39years, $40-49$ years and $>50$ years. This study demonstrated the ubiquitous presence of BPA in Malaysian rivers, probably as a result of industrial activities and sewage treatment plants. Nevertheless, exposure to BPA in the population coming from drinking water was low.

In 2013, Guo et al. published a study showing the levels of polycyclic aromatic hydrocarbon (PAH) metabolites in 306 urine samples collected in seven Asian countries (29 from Malaysia) (Guo et al., 2013). The study was focused on the general population and the PAHs metabolites analyzed were 2-hydroxynaphalene, 1-hydroxynaphalene, 2-hydroxyfluorene, 2-hydroxyphenanthrene, 3-hydroxyphenanthrene, 9-hydroxyphenanthrene, 4-hydroxyphenanthrene and 1-hydroxypyrene. Malaysian levels expressed as the sum of all metabolites were the lowest, with a median value of $226 \mathrm{pg}$ / $\mathrm{mL}$ vs the highest found in Kuwait $(10,170 \mathrm{pg} / \mathrm{mL})$.

Mohamed et al. collected hair samples from 124 Malaysian families and measured hair nicotine levels both in parents and in children (Mohamed et al., 2016). More than 50\% of the fathers reported smoking. The researchers found a statistically significant correlation between the hair nicotine levels in the mothers and the children $(p<0.001)$. Children living with smoking fathers had significantly higher hair nicotine level compared to children of non-smoking fathers (6.08 vs. $0.22 \mathrm{ng} / \mathrm{mg}$ ).

\subsection{Heavy metals}

\subsubsection{Lead, cadmium and arsenic}

Exposure to arsenic and cadmium via water supply in rural and urban communities was studied by Malaysian researchers (Zailina et al., 2014). They conducted a cross-sectional study analyzing concentrations of arsenic and cadmium in blood, urine and drinking water. The target population was residents in an urban and rural community with a total sample size of 100 volunteers (50 per area) from 20 to 50 years and living in the area for at least 5 years. They collected information about potential exposure confounders and socioeconomic, demographic, health status and occupation by face to face interviews.

\subsubsection{Mercury}

Praveena et al. published a review about mercury contamination in Malaysia in the environment, humans and food (Praveena et al., 2013). According to this work, exposure to mercury in the Malaysian population is related to seafood consumption, environmental conditions and different geographical areas. They identified the urgent needs and provided recommendations to conduct biomonitoring and research in Malaysia concerning mercury exposure.

\section{Indonesia}

Indonesia suffers from air pollution, specifically in big cities. In 2010, Jakarta had an annual mean $\mathrm{PM}_{2.5}$ level of over $20 \mu \mathrm{g} / \mathrm{m}^{3}$, more than twice the WHO guideline value of $10 \mu \mathrm{g} / \mathrm{m}^{3}$, mostly due to transportation. Of note, data from the World Bank showed that in 2017, $57.8 \%$ of the population in Jakarta suffers from various air pollutionrelated diseases (Yudha, 2017).

This rapid growth of the Indonesian economy, together with massive deforestation, caused additional environmental problems, including river water pollution. The Indonesian rivers, which are used for drinking and agriculture, were found to be highly polluted (Resosudarmo, 2003).

\subsection{Heavy metals}

\subsubsection{Mercury}

As in others countries of SE Asia the activities of small - scale gold mining present a serious problem from the point of view of the environmental and public health. Sari et al., 2016 studied mercury exposure from small - scale gold mining by comparing gold mining and non-mining areas in Cihonje, Central Java (Sari et al., 2016). They collected human hair samples, wastewater from gold mining, river water form Tajum River and collect health data by a questionnaire. Wastewater samples had mercury concentrations 2420 times higher than the maximum level permitted by the Indonesian regulation. High concentrations were also observed in river water, exceeding the quality threshold standards of the WHO. In humans, they found a maximum mercury level of $17 \mathrm{ng} / \mathrm{mg}$ in the gold mining region.

Bose-O'Reilly also performed studies focused on this target population in two regions, Galagan in Central Kalimantan and Talawaan in Northern Sulawesi, where previous studies reported severe mercury contamination in sediments and local fish. They investigated mercury level in blood, urine and hair samples from 281 volunteers and performed a questionnaire, neurological examination and neuro-psychological test (Bose-O'Reilly et al., 2010). The volunteers were classified in different groups in the selected regions: living in area but without occupational exposure to mercury; working with mercury but no smelting; working with mercury including smelting. A control group, without known special mercury burden, was established in the North Sulawesi region. The control group reported a high daily intake of fish and the median level observed was $4.42 \mu \mathrm{g} / \mathrm{L}$. Inorganic mercury in hair and mercury in urine were $0.13 \mu \mathrm{g} / \mathrm{g}$ hair and $0.73 \mu \mathrm{g} / \mathrm{L}$ respectively. They found statistically significant higher levels of mercury in the exposed groups. Amalgam-smelters showed mercury levels above the toxicological threshold limits in all the biological matrices studied. They found levels of mercury up to $5240 \mu \mathrm{g} / \mathrm{L}$ in urine, $429 \mu \mathrm{g} / \mathrm{L}$ in blood and $244 \mu \mathrm{g} / \mathrm{g}$ in hair. Their results reflected the high exposure to mercury associated to small-scale mining in these regions that provoke ataxia, tremor and movement disorders in the local population.

Samples of breast milk have been also used to assess exposure to mercury in small-scale gold mining areas. In 2003-2004 Bose-O'Reilly et al. studied 46 samples of exposed mothers form Kalimantan and Sulawesi in the framework of the UNIDO Global Mercury Project (BoseO'Reilly et al., 2008). The study also investigated levels in blood, urine and hair samples and involved women form Tanzania and Zimbabwe. The highest levels were found in those women that had occupational exposure as amalgam burners. They reported a median value of $3.23 \mu \mathrm{g} / \mathrm{g}(<0.20-52.98 \mu \mathrm{g} / \mathrm{g})$ for urine and $5.44 \mu \mathrm{g} / \mathrm{L}(0.83-42.4 \mu \mathrm{g} /$ L) for blood. For breast milk, the median was $1.87 \mu \mathrm{g} / \mathrm{L}$ and they found levels up to $149 \mu \mathrm{g} / \mathrm{L}$. The median for total mercury in hair was 
$1.93 \mu \mathrm{g} / \mathrm{g}$ (range: $0.32-103.19 \mu \mathrm{g} / \mathrm{g}$ ) and $0.70 \mu \mathrm{g} / \mathrm{g}$ and $0.94 \mu \mathrm{g} / \mathrm{g}$ for inorganic and organic mercury in hair respectively.

\subsubsection{Lead}

The use of leaded gasoline in Indonesia was recently banned, in 2001 in Jakarta and in 2006 in all cities of Indonesia (Santoso et al., 2011). The socioeconomic factors associated with exposure to lead in children were studied by Iriani et al. in 2012 . They analyzed blood lead in 108 children from 39 elementary schools and found significantly higher levels in males than in females $(6.8 \pm 2.0 \mu \mathrm{g} / \mathrm{dL}$ vs $5.9 \pm 1.9 \mu \mathrm{g} / \mathrm{dL}$ respectively, Iriani et al., 2012). The concentration for the total group was $6.4 \pm 2.0 \mu \mathrm{g} / \mathrm{dL}$ with a range of $2.9-12.5 \mu \mathrm{g} / \mathrm{dL}$. $7.5 \%$ of the children had lead levels above $10 \mu \mathrm{g} / \mathrm{dL}$. They observed an increase in lead levels in children with lower socioeconomic status associated with well water-drinking.

Haryanto assessed the potential health impacts of lead as consequence of the exposure coming from illegal lead acid battery smelters. They found that level of blood lead levels have increased by almost double in the period from 2011 to 2015 (Haryanto, 2016).

\subsection{Organic compounds}

In 2001-2003 Sudaryanto et al. studied levels of PBDEs (BDE-3, BDE-15, BDE-28, BDE-47, BDE-99, BDE-100, BDE-153, BDE-154, BDE183, BDE-196, BDE-197, BDE-206, BDE-207 and BDE-209) and organochlorines ( $\Sigma$ PCBs, p, $\mathrm{p}^{\prime}$-DDE, p, $\mathrm{p}^{\prime}$-DDD, p, $\mathrm{p}^{\prime}$-DDT, $\Sigma$ DDTs, $\alpha$-HCH, $\beta$ $\mathrm{HCH}, \gamma-\mathrm{HCH}$, $\Sigma \mathrm{HCH}$, oxy-CA, trans-Nona, cis-Nona, $\Sigma \mathrm{CHLs}$, HCB and TCPMe) (Sudaryanto et al., 2008). They analyzed a subset of 30 breast milk samples of the 100 samples collected in urban, suburban and rural regions. PBDEs were detected in all the samples with a total mean value of $2.2 \mathrm{ng} / \mathrm{g}$ lipid wt. and a range of $0.49-13 \mathrm{ng} / \mathrm{g}$ lipid wt. Considering the results per sampling locations, the mean concentrations were $2.2 \mathrm{ng} / \mathrm{g}$ lipid wt. in Jakarta (urban), $2.5 \mathrm{ng} / \mathrm{g}$ lipid wt. in Bogor (suburban), $2.6 \mathrm{ng} / \mathrm{g}$ lipid wt. in Purwakarta (rural) and $1.4 \mathrm{ng} / \mathrm{g}$ lipid wt. in Lampung (rural). The levels of OCs followed this trend: DDTs $>$ PCBs $>$ HCHs $>$ CHLs $>$ TCPMe $>$ PBDEs $>$ HCB.

\section{Conclusions and recommendations}

Human biomonitoring originated in the context of occupational health surveillance, where it is conducted to assess the risk of the workers exposure to hazards. The context of human biomonitoring, mostly in developed countries, has extended to the study of environmental exposures in the general population and specific sub-populations with special interest in children and pregnant women. This is also true for several SE Asian countries, such as Thailand, where it is used both in occupational and in general population contexts. In other countries included in this manuscript (Indonesia, Malaysia, Bangladesh) HBM studies are still mainly focused on occupational exposure and in hot spots, whereas in others (Myanmar) human biomonitoring is hardly conducted in any context.

Many SE Asia countries face similar challenges. Some of these challenges, such as air pollution from both ambient (e.g. vehicular emissions, industrial and open burning) and household sources (mainly from biomass combustion) and electronic waste processing, are global, while others, such as natural arsenic contaminated groundwater, the use of skin lightening creams, artisanal gold mining or the consumption of highly polluted fish and shellfish, are more specific to SE countries. HBM is an important tool to support environmental health protection policies. HBM data can identify subpopulations with elevated exposures, and provide evidence of the success, or lack thereof, of exposure mitigation measures.

We found that several SE Asian countries are using HBM tools to evaluate population exposure to environmental contaminants, however, there is high variability in the target chemicals and most studies focused on classic pollutants such as heavy metals and current use pesticides. Also, there is high variability in the studied population and a lack of common protocols for pre-analytic and analytical phases. Many of the studies reviewed in this work did not have sufficient QC/QA and were not performed in accredited laboratories.

The increasing use of HBM together with the existence of common challenges paves the way to work for the establishment of a harmonized approach for HBM in SE Asia. The implementation of HBM studies in a harmonized way has clear benefits, including improvement in the comparability of the results, improved quality of the chemical results, capacity building, and more efficient use of resources. These benefits and the possibility of implementation were proven in COPHES (COnsortium to Perform Human biomonitoring on a European Scale) and DEMOCOPHES (DEMOnstration of a study to COordinate and Perform Human biomonitoring on a European Scale) with a coordinated HBM study performed in 17 countries involving the analysis of mercury, cadmium, cotinine, phthalates metabolites and bisphenol A in $>3600$ volunteers.

Taking COPHES/DEMOCOPHES as an example, and considering the differences, collaboration between SE Asian countries on HBM studies will be of great benefit to the countries and will have an impact on additional countries, both in SE-Asia and others. Since HBM analytical instrumentation is highly expensive and since HBM studies require a high level of expertise, both technical and scientific, we recommend establishing a regional HBM laboratory or laboratories in SE Asia and increasing collaborations between researchers in this region. However, we note that a regional laboratory may present bureaucratic, ethical, and administrative challenges regarding cross-country and cross-continent shipments of samples.

Collaboration between international experts or consortiums with long experience in HBM studies and programs may further accelerate progress in this field and can help gain political and financial support for HBM in these countries. In the case of Israel, for example, consultation and collaboration with leading international HBM experts in the US and Europe has been crucial, both for technical issues related to QC/QA but also for scientific issues related to data analysis and interpretation (Berman et al., 2017). We note that a number of the studies we reviewed were conducted in collaboration with international experts, notably several studies in Thailand and two studies in Burmese populations. Collaboration with HBM experts in neighboring SE Asian countries, like those involved in the Korean National Environmental Health Surveys (KoNEHS), would be beneficial.

Sharing of protocols and training sessions would provide a jump start for resource poor countries. This has been recently demonstrated in a UNEP/WHO in the framework of the Minamata Convention for the development of a Plan for Global Monitoring of Human Exposure to and Environmental Concentrations of Mercury (UN Environment, 2018). This could be a good starting point since mercury exposure is a widespread problem in many SE Asian countries. Sharing protocols, or developing common protocols, for sampling strategies and selected biological media for HBM studies could increase data comparability between different SE Asian countries, and with other populations.

We emphasize the need for the improvement of QA/QC in HBM studies. QA/QC are critical steps for achieving reliable and comparable HBM results, and relate to several stages of HBM studies including sampling, storage, transportation, and laboratory analysis. As part of the aforementioned COPHES/DEMOCOPHES project, a Quality Assurance Unit (QAU) was established and provided participating laboratories with standard operating procedures and with control material for testing sample homogeneity and stability. In addition, qualified laboratories served as reference laboratories for evaluating the performance of participating laboratories (Esteban et al., 2015; Schindler et al., 2014).

In conclusion, in light of increasing exposure to environmental contaminants in SE Asia, together with the need for information to support policy decision making, there is a need to further development of HBM in SE Asia. We found that HBM studies have been conducted in 
SE Asian countries on an array of environmental chemicals, mostly heavy metals, but that many studies lack QA/QC, and that results from studies are generally not comparable because of differences in selected study populations and target chemicals. Our recommendations include establishment of a regional HBM laboratory or laboratories in SE Asia; increasing collaboration with international HBM experts or programs; sharing of protocols and training sessions; and improving QA/QC in HBM studies conducted in SE Asia. Increasing use of HBM in SE Asian countries could contribute to improved environmental health policy making, for example in designing targeted interventions following identification of highly exposed sub-populations in HBM studies.

Supplementary data to this article can be found online at https:// doi.org/10.1016/j.envint.2018.03.046.

\section{Acknowledgements}

The work of the first author was supported by the Environment and Health Fund, Jerusalem, Israel.

\section{References}

Apinan, R., Satarug, S., Ruengweerayut, R., Mahavorasirikul, W., Na-Bangchang, K., 2010. The influence of iron stores on cadmium body burden in a Thai population. Environ. Geochem. Health 32 (3), 237-242.

Asawasinsopon, R., Prapamontol, T., Prakobvitayakit, O., Vaneesorn, Y., Mangklabruks, A., Hock, B., 2006. The association between organochlorine and thyroid hormone levels in cord serum: a study from northern Thailand. Environ. Int. 32, 554-559.

Bacquart, T., Frisbie, S., Mitchell, E., Grigg, L., Cole, C., Small, C., Sarkar, B., 2015. Multiple inorganic toxic substances contaminating the groundwater of Myingyan Township, Myanmar: arsenic, manganese, fluoride, iron, and uranium. Sci. Total Environ. 517, 232-245. http://dx.doi.org/10.1016/j.scitotenv.2015.02.038.

Berman, T., Goldsmith, R., Levine, H., Grotto, I., 2017. Human biomonitoring in Israel: Recent results and lessons learned. Int. J. Hyg. Environ. Health 220 (2 Pt A), 6-12. http://dx.doi.org/10.1016/j.ijheh.2016.09.008.

Boonprasert, K., Kongjam, P., Limpatanachote, P., Ruengweerayut, R., Na-Bangchang, K., 2011. Urinary and blood cadmium levels in relation to types of food and water intake and smoking status in a Thai population residing in cadmium-contaminated areas in Mae Sot. Southeast Asian J. Trop. Med. Public Health 42 (6), 1521-1530.

Bose-O'Reilly, S., Drasch, G., Beinhoff, C., Rodrigues-Filho, S., Roider, G., Lettmeier, B., Maydl, A., Maydl, S., Siebert, U., 2010. Health assessment of artisanal gold miners in Indonesia. Sci. Total Environ. 408 (4), 713-725.

Bose-O'Reilly, S., Lettmeier, B., Roider, G., Siebert, U., Drasch, G., 2008. Mercury in breast milk - a health hazard for infants in gold mining areas? Int. J. Hyg. Environ. Health 211 (5-6), 615-623.

Centers for Disease Control and Prevention (CDC), 2017. National Biomonitoring Program. https://www.cdc.gov/biomonitoring/ (accessed 18 January 2018).

Chakraborti, D., Rahman, M.M., Mukherjee, A., Alauddin, M., Hassan, M., Dutta, R.N., Pati, S., Mukherjee, S.C., Roy, S., Quamruzzman, Q., Rahman, M., Morshed, S., Islam, T., Sorif, S., Selim, M., Islam, M.R., Hossain, M.M., 2015. Groundwater arsenic contamination in Bangladesh-21 years of research. J. Trace Elem. Med. Biol. 31, 237-248.

Cohen, A.J., Brauer, M., Burnett, R., Anderson, H.R., Frostad, J., Estep, K., Balakrishnan, K., Brunekreef, B., Dandona, L., Dandona, R., Feigin, V., Freedman, G., Hubbell, B., Jobling, A., Kan, H., Knibbs, L., Liu, Y., Martin, R., Morawska, L., Pope 3rd, C.A., Shin, H., Straif, K., Shaddick, G., Thomas, M., van Dingenen, R., van Donkelaar, A., T5, Vos, Murray, C.J.L., Forouzanfar, M.H., 2017. Estimates and 25-year trends of the global burden of disease attributable to ambient air pollution: an analysis of data from the Global Burden of Diseases Study 2015. Lancet 389 (10082), 1907-1918. http://dx.doi.org/10.1016/S0140-6736(17)30505-6.

Damrongsiri, S., Vassanadumrongdee, S., Tanwattana, P., 2016. Heavy metal contamination characteristic of soil in WEEE (waste electrical and electronic equipment) dismantling community: a case study of Bangkok, Thailand. Environ. Sci. Pollut. Res. Int. 23 (17), 17026-17034.

Diaconu, L., 2014. The foreign direct investments in South-East Asia during the last two decades. Procedia Economics and Finance. 15, 903-908.

Edmunds, W.M., Ahmedb, K.M., Whitehead, P.G., 2015. A review of arsenic and its impacts in groundwater of the Ganges-Brahmaputra-Meghna delta, Bangladesh. Environ. Sci.: Processes Impacts 17, 1032.

Esteban, M., Schindler, B.K., Jiménez-Guerrero, J.A., Koch, H.M., Angerer, J., Rosado, M., Rivas, T.C., Gómez, S., Casteleyn, L., Kolossa-Gehring, M., Becker, K., Bloemen, L., Schoeters, G., Den Hond, E., Sepai, O., Exley, K., Horvat, M., Knudsen, L.E., Joas, A., Joas, R., Aerts, D., Biot, D., Borošová, D., Davidson, F., Dumitrascu, I., Fischer, M.E., Grander, M., Janasik, B., Jones, K., Kašparová, L., Larssen, T., Naray, M., Nielsen, F., Hohenblum, P., Pinto, R., Pirard, C., Plateel, G., Tratnik, J.S., Wittsiepe, J., Castaño, A., Reference Laboratories, E.Q.U.A.S., 2015. Mercury analysis in hair: comparability and quality assessment within the transnational COPHES/DEMOCOPHES project. Environ. Res. 141, 24-30.

Fiedler, N., Rohitrattana, J., Siriwong, W., Suttiwan, P., Ohman Strickland, P., Ryan, P.B., Rohlman, D.S., Panuwet, P., Barr, D.B., Robson, M.G., 2015. Neurobehavioral effects of exposure to organophosphates and pyrethroid pesticides among Thai children. Neurotoxicology 48, 90-99. http://dx.doi.org/10.1016/j.neuro.2015.02.003.

Fry, R.C., Navasumrit, P., Valiathan, C., Svensson, J.P., Hogan, B.J., Luo, M., Bhattacharya, S., Kandjanapa, K., Soontararuks, S., Nookabkaew, S., Mahidol, C., Ruchirawat, M., Samson, L.D., 2007. Activation of inflammation/NF-kappaB signaling in infants born to arsenic-exposed mothers. PLoS Genet. 3 (11), e207.

George, C.M., Gamble, M., Slavkovich, V., Levy, D., Ahmed, A., Ahsan, H., Graziano, J. 2013. A cross-sectional study of the impact of blood selenium on blood and urinary arsenic concentrations in Bangladesh. Environ. Health 12, 52.

Gleason, K., Shine, J.P., Shobnam, N., Rokoff, L.B., Suchanda, H.S., Ibne Hasan, M.O., Mostofa, G., Amarasiriwardena, C., Quamruzzaman, Q., Rahman, M., Kile, M.L., Bellinger, D.C., Christiani, D.C., Wright, R.O., Mazumdar, M., 2014. Contaminated turmeric is a potential source of lead exposure for children in rural Bangladesh. J. Environ. Public Health 2014, 730636.

Guo, Y., Alomirah, H., Cho, H.S., Minh, T.B., Mohd, M.A., Nakata, H., Kannan, K., 2011. Occurrence of phthalate metabolites in human urine from several Asian countries. Environ. Sci. Technol. 45 (7), 3138-3144. http://dx.doi.org/10.1021/es103879m.

Guo, Y., Senthilkumar, K., Alomirah, H., Moon, H.B., Minh, T.B., Mohd, M.A., Nakata, H., Kannan, K., 2013. Concentrations and profiles of urinary polycyclic aromatic hydrocarbon metabolites (OH-PAHs) in several Asian countries. Environ. Sci. Technol. 47 (6), 2932-2938. http://dx.doi.org/10.1021/es3052262.

Haque, M.A., Barman, N., Islam, M.T., Mannan, M., Khan, M.H., Karim, M.R., Rob, M.A., Hossain, M.A., 2016. Biomass fuel smoke and tuberculosis: a case-control study. Mymensingh Med. J. 25 (1), 31-38.

Haryanto, B., 2016. Lead exposure from battery recycling in Indonesia. Rev. Environ. Health 31 (1), 13-16.

Hinhumpatch, P., Navasumrit, P., Chaisatra, K., Promvijit, J., Mahidol, C., Ruchirawat, M., 2013. Oxidative DNA damage and repair in children exposed to low levels of arsenic in utero and during early childhood: application of salivary and urinary biomarkers. Toxicol. Appl. Pharmacol. 273 (3), 569-579.

Iriani, D.U., Matsukawa, T., Tadjudin, M.K., Itoh, H., Yokoyama, K., 2012. Cross-sectional study on the effects of socioeconomic factors on lead exposure in children by gender in Serpong, Indonesia. Int. J. Environ. Res. Public Health 9 (11), 4135-4149. http:// dx.doi.org/10.3390/ijerph9114135.

Islam, M.R., Attia, J., Alauddin, M., McEvoy, M., McElduff, P., Slater, C., Islam, M.M., Akhter, A., d'Este, C., Peel, R., Akter, S., Smith, W., Begg, S., Milton, A.H., 2014. Availability of arsenic in human milk in women and its correlation with arsenic in urine of breastfed children living in arsenic contaminated areas in Bangladesh. Environ. Health 13, 101. http://dx.doi.org/10.1186/1476-069X-13-101.

Kaw, H.Y., Kannan, N., 2017. A review on polychlorinated biphenyls (PCBs) and polybrominated diphenyl ethers (PBDEs) in South Asia with a focus on Malaysia. Rev. Environ. Contam. Toxicol. 242, 153-181. http://dx.doi.org/10.1007/398_2016_14.

Kibria, G., Hossain, M.M., Mallick, D., Lau, T.C., Wu, R., 2016. Trace/heavy metal pollution monitoring in estuary and coastal area of Bay of Bengal, Bangladesh and implicated impacts. Mar. Pollut. Bull. 105 (1), 393-402.

Kippler, M., Nermell, B., Hamadani, J., Tofail, F., Moore, S., Vahter, M., 2010. Burden of cadmium in early childhood: longitudinal assessment of urinary cadmium in rural Bangladesh. Toxicol. Lett. 198 (1), 20-25.

Kippler, M., Tofail, F., Hamadani, J.D., Gardner, R.M., Grantham-McGregor, S.M., Bottai, M., Vahter, M., 2012. Early-life cadmium exposure and child development in 5-yearold girls and boys: a cohort study in rural Bangladesh. Environ. Health Perspect. 120 (10), 1462-1468.

Kongtip, P., Nankongnab, N., Woskie, S., Phamonphon, A., Tharnpoophasiam, P., Wilaiwan, K., Srasom, P., 2014. Organophosphate urinary metabolite levels during pregnancy, delivery and postpartum in women living in agricultural areas in Thailand. J. Occup. Health 55 (5), 367-375.

Liu, H., Hanchenlaksh, C., Povey, A.C., de Vocht, F., 2015. Pesticide residue transfer in Thai farmer families: using structural equation modeling to determine exposure pathways. Environ. Sci. Technol. 49 (1), 562-569 6.

McKelvey, W., Jeffery, N., Clark, N., Kass, D., Parsons, P., 2011. Population-based inorganic mercury biomonitoring and the identification of skin care products as a source of exposure in New York City. Environ. Health Perspect. 119 (2), 203-209. http://dx.doi.org/10.1289/ehp.1002396.

Mitchell, T., Jentes, E., Ortega, L., Scalia Sucosky, M., Jefferies, T., Bajcevic, P., Parr, V., Jones, W., Brown, M.J., Painter, J., 2012. Lead poisoning in United States-bound refugee children: Thailand-Burma border, 2009. Pediatrics 129 (2), e392-9. http:// dx.doi.org/10.1542/peds.2011-1218.

Mohamed, N.N., Loy, S.L., Man, C.N., Al-Mamun, A., Jan Mohamed, H.J., 2016. Higher hair nicotine level in children compared to mother living with smoking father in Malaysia. Environ. Health Prev. Med. 21 (6), 572-578.

Nahar, M.N., Inaoka, T., Fujimura, M., 2014. A consecutive study on arsenic exposure and intelligence quotient (IQ) of children in Bangladesh. Environ. Health Prev. Med. 19 (3), 194-199.

Naksen, W., Prapamontol, T., Mangklabruks, A., Chantara, S., Thavornyutikarn, P., Srinual, N., Panuwet, P., Ryan, P.B., Riederer, A.M., Barr, D.B., 2015. Associations of maternal organophosphate pesticide exposure and PON1 activity with birth outcomes in SAWASDEE birth cohort, Thailand. Environ. Res. 142, 288-296.

National Research Council (NRC), 2006. Human Biomonitoring for Environmental Chemicals. Committee on Human Biomonitoring for Environmental Toxicants. Washington DC. The National Academies Press. https://www.nap.edu/read/11700/ chapter/1 (accessed 18 January 2018).

Nishijo, M., Suwazono, Y., Ruangyuttikarn, W., Nambunmee, K., Swaddiwudhipong, W. Nogawa, K., Nakagawa, H., 2014. Risk assessment for Thai population: benchmark dose of urinary and blood cadmium levels for renal effects by hybrid approach of inhabitants living in polluted and non-polluted areas in Thailand. BMC Public Health 14,702 
Panuwet, P., Siriwong, W., Prapamontol, T., Ryan, P.B., Fiedler, N., Robson, M.G., Barr, D.B., 2012. Agricultural pesticide management in Thailand: situation and population health risk. Environ. Sci. Pol. 17, 72-81.

Poon, W.C., Herath, G., Sarker, A., Masuda, T., Kada, R., 2016. River and fish pollution in Malaysia: a green ergonomics perspective. Appl. Ergon. 57, 80-93. http://dx.doi.org/ 10.1016/j.apergo.2016.02.009.

Praveena, S.M., de Burbure, C., Aris, A.Z., Hashim, Z., 2013. Mini review of mercury contamination in environment and human with an emphasis on Malaysia: status and needs. Rev. Environ. Health 28 (4), 195-202.

Rahman, A., Vahter, M., Smith, A.H., Nermell, B., Yunus, M., El Arifeen, S., Persson, L.A., Ekström, E.C., 2009. Arsenic exposure during pregnancy and size at birth: a prospective cohort study in Bangladesh. Am. J. Epidemiol. 169 (3), 304-312.

Rana, M.M., Sulaiman, N., Sivertsen, B., Khan, M.F., Nasreen, S., 2016. Trends in atmospheric particulate matter in Dhaka, Bangladesh, and the vicinity. Environ. Sci. Pollut. Res. Int. 23 (17), 17393-17403. http://dx.doi.org/10.1007/s11356-0166950-4.

Resosudarmo, B.P., 2003. River water pollution in Indonesia: an input-output analysis. Int. J. Environ. Sust. 2, 62-77.

Ritchey, M.D., Scalia Sucosky, M., Jefferies, T., McCormick, D., Hesting, A., Blanton, C., Duwve, J., Bruner, R., Randolph Daley, W., Jarrett, J., Brown, M.J., 2011. Lead poisoning among Burmese refugee children-Indiana, 2009. Clin. Pediatr. (Phila). 50 (7), 648-656. http://dx.doi.org/10.1177/0009922811398958.

Rohitrattana, J., Siriwong, W., Robson, M., Panuwet, P., Barr, D.B., Fiedler, N., 2014. Pyrethroid insecticide exposure in school-aged children living in rice and aquacultural farming regions of Thailand. Risk Manag. Healthc. Policy. 7, 211-217.

Rohitrattana, J., Siriwong, W., Tunsaringkarn, T., Panuwet, P., Ryan, P.B., Barr, D.B., Robson, M.G., Fiedler, N., 2014. Organophosphate pesticide exposure in school-aged children living in rice and aquacultural farming regions of Thailand. 2014. J. Agromedicine 19 (4), 406-416.

Santhi, V.A., Sakai, N., Ahmad, E.D., Mustafa, A.M., 2012. Occurrence of bisphenol A in surface water, drinking water and plasma from Malaysia with exposure assessment from consumption of drinking water. Sci. Total Environ. 427-428, 332-338. http:// dx.doi.org/10.1016/j.scitotenv.2012.04.041.

Santoso, M., Lestiani, D., Mukhtar, R., Hamonangan, E., Syafrul, H., Markwitz, A., Hopke, P., 2011. Preliminary study of the sources of ambient air pollution in Serpong, Indonesia. Atmos. Pollut. Res. 2, 190-196.

Sari, M.M., Inoue, T., Matsumoto, Y., Yokota, K., 2016. Measuring total mercury due to small-scale gold mining activities to determine community vulnerability in Cihonje, Central Java, Indonesia. Water Sci. Technol. 73 (2), 437-444.

Satarug, S., Ujjin, P., Vanavanitkun, Y., Baker, J.R., Moore, M.R., 2004. Influence of body iron store status and cigarette smoking on cadmium body burden of healthy Thai women and men. Toxicol. Lett. 148 (3), 177-185.

Sayeg, P., 1998. Successful Conversion to Unleaded Gasoline in Thailand. World Bank, Washington. http://documents.worldbank.org/curated/en/530551468778459674/ Successful-conversion-to-unleaded-gasoline-in-Thailand (accessed 18 January 2018).

Schindler, B.K., Esteban, M., Koch, H.M., Castano, A., Koslitz, S., Cañas, A., Casteleyn, L., Kolossa-Gehring, M., Schwedler, G., Schoeters, G., Hond, E.D., Sepai, O., Exley, K., Bloemen, L., Horvat, M., Knudsen, L.E., Joas, A., Joas, R., Biot, P., Aerts, D., Lopez, A., Huetos, O., Katsonouri, A., Maurer-Chronakis, K., Kasparova, L., Vrbík, K., Rudnai P Naray, M., Guignard, C., Fischer, M.E., Ligocka, D., Janasik, B., Reis, M.F., Namorado, S., C2, Pop, Dumitrascu, I., Halzlova, K., Fabianova, E., Mazej, D., Tratnik, J.S., Berglund, M., Jönsson, B., Lehmann, A., Crettaz, P., Frederiksen, H., Nielsen, F., McGrath, H., Nesbitt, I., De Cremer, K., Vanermen, G., Koppen, G., Wilhelm, M., Becker, K., Angerer, J., 2014. The European COPHES/DEMOCOPHES project: towards transnational comparability and reliability of human biomonitoring results. Int. J. Hyg. Environ. Health 217 (6), 653-661.

Sirivarasai, J., Kaojarern, S., Wananukul, W., Deechakwan, W., Srisomerarn, P., 2004. Non-occupational lead and cadmium exposure and blood pressure in Thai men. Asia Pac. J. Public Health 16 (2), 133-137.

Stuetz, W., Prapamontol, T., Erhardt, J.G., Classen, H.G., 2001. Organochlorine pesticide residues in human milk of a Hmong hill tribe living in northern Thailand. Sci. Total
Environ. 273, 53-60

Sudaryanto, A., Kajiwara, N., Takahashi, S., Muawanah, Tanabe, S., 2008. Geographical distribution and accumulation features of PBDEs in human breast milk from Indonesia. Environ. Pollut. 151 (1), 130-138.

Sudaryanto, A., Kunisue, T., Tanabe, S., Niida, M., Hashim, H., 2005. Persistent organochlorine compounds in human breast milk from mothers living in Penang and Kedah, Malaysia. Arch. Environ. Contam. Toxicol. 49 (3), 429-437.

Swaddiwudhipong, W., Mahasakpan, P., Jeekeeree, W., Funkhiew, T., Sanjum, R., Apiwatpaiboon, T., Phopueng, I., 2015. Renal and blood pressure effects from environmental cadmium exposure in Thai children. Environ. Res. 136, 82-87.

Swaddiwudhipong, W., Nguntra, P., Kaewnate, Y., Mahasakpan, P., Limpatanachote, P., Aunjai, T., Jeekeeree, W., Punta, B., Funkhiew, T., Phopueng, I., 2015. Human health effects from cadmium exposure: comparison between persons living in cadmiumcontaminated and non-contaminated areas in northwestern Thailand. Southeast Asian J. Trop. Med. Public Health 46 (1), 133-142.

Swaddiwudhipong, W., Tontiwattanasap, W., Khunyotying, W. Sanreun, C., 2013, Blood lead levels among rural Thai children exposed to lead-acid batteries from solar energy conversion systems. Southeast Asian J. Trop. Med. Public Health 44 (6), 1079-1087.

Tanabe, S., Kunisue, T., 2007. Persistent organic pollutants in human breast milk from Asian countries. Environ. Pollut. 146 (2), 400-413.

Tao, L., Ma, J., Kunisue, T., Libelo, E.L., Tanabe, S., Kannan, K., 2008. Perfluorinated compounds in human breast milk from several Asian countries, and in infant formula and dairy milk from the United States. Environ. Sci. Technol. 42 (22), 8597-8602.

Teeyapant, P., Leudang, S., Parnmen, S., 2015. A cross-sectional study of exposure to mercury in schoolchildren living near the eastern seaboard industrial estate of Thailand. WHO South East Asia J. Public Health. 4 (1), 45-53.

Thaweboon, S., Thaweboon, B., Veerapradist, W., 2005. Lead in saliva and its relationship to blood in the residents of Klity Village in Thailand. Southeast Asian J. Trop. Med. Public Health 36 (6), 1576-1579.

UN Environment, 2018. Global Mercury Monitoring Project. http://web.unep.org/ chemicalsandwaste/what-we-do/science-and-knowledge/issues-concern/mercurywaste-management-and-monitoring/global (Accessed 19 January 2018).

Vaneesorn, Y., Mangklabruks, A., Hock, B., 2006. Plasma levels of DDT and their association with reproductive hormones in adult men from northern Thailand. Sci. Total Environ. 355, 98-105.

Vichit-Vadakan, N., Vajanapoom, N., 2011. Health impact from air pollution in Thailand: current and future challenges. Environ. Health Perspect. 119 (5), A197-8.

Wananukul, W., Sirivarasai, J., Sriapha, C., Chanatara, V., Chunvimaluang, N., Keanpoompuang, A., Boriboon, W., Pumala, K., Kaojarern, S., 1998. Lead exposure and accumulation in healthy Thais: assessed by lead levels, EDTA mobilization and heme synthesis-related parameters. J. Med. Assoc. Thail. 81 (2), 110-116.

World Health Organization (WHO), 2016. Climate and Health Country Profile - 2015 Myanmar. http://www.searo.who.int/entity/water_sanitation/mmr_c_h_profile.pdf? ua $=1$ (Accessed 18 January 2018).

World Health Organization (WHO) Europe, 2015. Human Biomonitoring: Facts and Figures. WHO Regional Office for Europe, Copenhagen, pp. 2015. http://www.euro who.int/_data/assets/pdf_file/0020/276311/Human-biomonitoring-facts-figuresen.pdf (Accessed 3 March 2018).

Yudha, S.W., 2017. Air Pollution and Its Implications for Indonesia: Challenges and Imperative for Change. http://pubdocs.worldbank.org/en/183201496935944434/ 200417-AirQualityAsia-Air-Pollution.pdf, Accessed date: 19 January 2018.

Zailina, H., Najibah, H., Aiezzati, A.N., Praveena, S.M., Patimah, I., 2014. Comparison of the health implications on the use of As and Cd contaminated water supply between urban and rural communities. Biomed. Res. Int. 2014, 797603.

Zamir, R., Athanasiadou, M., Nahar, N., Mamun, M.I., Mosihuzzaman, M., Bergman, A., 2009. Persistent organohalogen contaminants in plasma from groups of humans with different occupations in Bangladesh. Chemosphere 74 (3), 453-459.

Zhang, Z., Alomirah, H., Cho, H.S., Li, Y.F., Liao, C., Minh, T.B., Mohd, M.A., Nakata, H. Ren, N., Kannan, K., 2011. Urinary bisphenol A concentrations and their implications for human exposure in several Asian countries. Environ. Sci. Technol. 45 (16), 7044-7050. 